\title{
E-democracy Applications in Greek Social Enterprises
}

\author{
Panagiotis Kotsios ${ }^{1}$, Christos Triantafyllopoulos ${ }^{2}$ \\ ${ }^{1}$ School of Social Sciences, Hellenic Open University, Patra, Greece \\ ${ }^{2}$ Ministry of Finance, Athens, Greece \\ Correspondence: Dr. Panagiotis Kotsios, Hellenic Open University, Patra, 26335, Greece.
}

Received: October 30, 2020

Accepted: December 9, 2020

Online Published: December 18, 2020

doi:10.5539/ibr.v14n1p79

URL: https://doi.org/10.5539/ibr.v14n1p79

\begin{abstract}
Electronic democracy and its features are slowly starting to be adopted in various countries and organisations across the world, as its practical advantages are gradually being recognised and concerns about security are being dealt with. Meanwhile, social enterprises are rising as a strong alternative against the purely private economy, and for this type of enterprises, democracy is in the core of their governance process. However, the links between these two topics remain unexplored. The current research investigated the use of e-democracy applications by Greek social enterprises, as well as the opinions of their members regarding the value of e-democracy. The results show relatively small adoption rate, but wide interest in merging e-democracy procedures in their daily activities.
\end{abstract}

Keywords: social enterprises, electronic democracy, applications, research

\section{Introduction}

Our era is characterized by widespread desire to improve political systems for the purpose of the common good. At least in the the European Union, large citizen distrust for the political system is fuelled by problems faced by large parts of the European population, as economic crises, inequality, unemployment, corruption scandals and environmental pollution. The results of the Eurobarometer are revealing: on 2018, only 41\% of Europeans trusted the European Union, while $48 \%$ did not (11\% expressed no opinion). Trust levels of European institutions were similarly low: the European Commission was distrusted by 58\% of Europeans; the European Central Bank was distrusted by $61 \%$ and the European Parliament by 55\%. Satisfaction with the way national democratic systems operate, was very low also: only $56 \%$ of Europeans were satisfied with the way democracy worked in their country, while $42 \%$ were dissatisfied ( $2 \%$ expressed no opinion). The country with the highest dissatisfaction rate at national level was Greece with $77 \%$, followed by Croatia with $72 \%$, Lithuania and Romania with $64 \%$ and Italy with $61 \%$.

Significant improvements to the European and national political systems may come from technological innovations that can simplify and promote active political involvement, information sharing, communication and participation in the decision-making process for larger parts of the population. These innovations are all included under the umbrella of electronic democracy - the practice of democracy with the support of digital media in political communication and participation (Korthagen et al, 2018). The idea of using electronic democracy in order to promote political participation however is not new; these ideas started appearing a few years after the widespread adoption of personal computers and the internet. However, today, after 25 years of e-democracy discussions and theory development, its use is still limited. There have been various applications and paradigms at municipality, trade union, political party, enterprise as well as at national level, but the general adoption rate and the spectrum of uses is still very limited.

Meanwhile, globally, the social economy and social enterprises are being increasingly recognised as an effective tool for combating poverty, empowering vulnerable social groups, creating employment and promoting social cohesion. Policymakers in Europe have shown an increasing interest on the topic. The European Commission has placed the social economy and social enterprises at the heart of its concerns, in terms of both territorial cohesion and the search for new solutions to societal problems, in particular the fight against poverty and exclusion (European Commission, 2011). In addition, for this type of enterprises, democracy is in the core of their governance process. However, the links between electronic democracy and social enterprises remain unexplored. It is possible that, wider e-democracy application adoption, to have to start at social enterprise level, 
in order to evolve, adapt and pass into much larger audiences.

On this context, the goal of this research was to explore the use of e-democracy applications by Greek social enterprises, as well as the opinions of their members regarding the value of e-democracy. The research starts with a short literature review about social economy and social enterprises, the state of social economy in Greece and the role of democratic procedures in the governance of social enterprises. Next is a description of the term electronic democracy and the progress in its implementation, followed by an outline of the specific research questions. After is a description of the methodology that was applied for the data collection, and the presentation of the results from the online search and the survey on Greek social enterprises. The last part of the study includes the conclusions, limitations and directions for future research.

\section{Literature Review}

\subsection{Social Economy}

The term social economy appeared in economic literature for the first time in 1830, by the French economist Charles Dunoyer, in a treatise advocating an ethical approach to economics (Monzon and Chaves, 2012). Since then, the concept of social economy has evolved and transformed in order to keep pace with the developments in the organizations that are related with it (Noya \& Clarence, 2007). Mertens (1999) placed social economy between the private and the public sector, while the term social economy has in the past been attributed to a number of alternative concepts, such as the third sector, the non-profit sector, the solidarity economy, the alternative economy and the non-profit economy (Westlund, 2003). Nikolaou (2014) mentions that the social economy exists in order to meet social needs that the private sector is not willing to cover due to the absence of sufficient profits and the public sector cannot cover due to lack of financial resources. Uluorta (2009) describes the social economy as a set of networks that operate outside the market economy and the state, and are intended to ensure social reproduction. Correspondingly, Noya and Clarence (2007, p. 10) argue that "what is critical to the idea of social economy is that it seeks to capture both the social and the economic element, and this is inherent in those organizations that occupy the space between the market and the state ".

However, despite efforts by academics, international organizations, EU institutions, national governments and representatives of the social economy, to produce a common analytical framework, there is still no universally accepted definition of social economy. This is due to the fact that the social economy comprises various activities, many forms of entities carrying out these activities, and difficulty to distinguish these entities from other private economic actors and the public sector (Liger et al, 2016). The European Commission's Directorate-General for Internal Market, Industry, Entrepreneurship and SMEs (2019) mentions that the social economy aims to generate profits for people who are not investors or owners of a business. Liger aet al (2016), in their report for the European Commission, proposed the following definition: "the social economy consists of private, officially organized enterprises and networks operating under democratic and participatory decision-making processes, producing commercially non-goods and services" (p. 28). In this context, the authors proposed some key features for the classification of actors in the social economy and their separation from other enterprises:

- The supremacy of the individual: the social economy is based on the supremacy of the individual and social goals over capital,

- Sustainable development: the overall objective of social economy activities does not emphasize the pursuit of profit and its distribution to owners,

- Social and economic equilibrium: in the performance of their activities, social economy actors focus on social objectives;

- Democratic governance and ownership: the actors of the social economy operate according to democratic, transparent and participatory decision-making processes.

The main operators of social economy and entrepreneurship are social enterprises. The term covers a wide range of legal forms of business, organizations, initiatives, activities and industries, with several differences from country to country. The European Commission's Social Enterprise Initiative mentions that "a social enterprise is an operator in the social economy whose main objective is to have a social impact rather than make a profit for their owners or shareholders. It operates by providing goods and services for the market in an entrepreneurial and innovative fashion and uses its profits primarily to achieve social objectives" (p.2). More specifically the Commission uses the term 'social enterprise' to cover the following types of business:

- Those for which the social purpose of the common good is the cause of commercial activity,

- Those in which profits are reinvested mainly for the attainment of that social purpose, 
- Those where the method of organization or system of ownership reflects their mission, using democratic or participatory principles or focusing on social justice.

The main actors of social economy and entrepreneurship in the European Union are: a) cooperatives, b) mutuals, c) associations, d) foundations and e) other types of social enteprises (Monzon \& Chaves, 2012). Today, its estimated that there are approximately 2 million social economy entities in Europe, representing around 10-12\% of all European businesses. Traditional social economy entities (co-operatives, affiliates and mutuals) employed over 14 million people in 2010 , accounting for $6.5 \%$ of the total economically active population of the EU, from 11 million and 6.5\% in 2002 (European Commission, 2019).

\subsection{Social Economy in Greece}

Greece has a long history within the era of social economy, even though its official recognition was quite recent. The Common Company of Ampelakia, a very successful agriculture and manufacturing cooperative, founded in 1750 in the prefecture of Thessalia in Central Greece, is considered the first modern cooperative of the world. However, the official legislation on social enterprises in Greece begins with Law 602 of 1914 and the recognition of agricultural cooperatives, the publication of the Civil Code of 1946 about non-profit civil societies, Law 1667 of 1986 about civil cooperatives and law 2716 of 1999 about Social Limited Liability Cooperatives.

The most recent Law on Social and Solidarity Economy is 4430/2016, which defined the Social and Solidarity Economy as: "all economic activities based on an alternative form of organization of production, distribution, consumption and reinvestment relations based on principles of democracy, equality, solidarity, cooperation, and respect for human beings and the environment". This law recognises as Social and Solidarity Entities: a) Social Cooperative Enterprises; (b) Social Limited Liability Cooperatives, c) Workers' Associations and d) any other non-sole proprietorship entity with established legal identity that follows the rules about dispersion of profits, democratic governance and some more criteria.

Regarding their number of entities that fall on the general category of the social economy, in 2019, across the country, there were 608 active agricultural cooperatives (Ministry of Agricultural Development, 2019), 590 active civil cooperatives (National Business Registry), 1.363 Social Cooperative Enterprises 28 Social Limited Liability Cooperatives and 25 Workers' Associations, (Ministry of Labor and Social Affairs, 2019). There are no available open data about the number of Civil Societies, Unions, foundations etc.

\subsection{Democratic Governance}

As mentioned earlier, perhaps the most distinct characteristic of social enterprises, apart from the pursuit of social goals along with the economic ones, is democratic governance. All the reports from the European Commission and the European Parliament refer to the democratic governance as a key characteristic of social enterprises. The International Cooperative Alliance (ICA) in 1995 adopted the revised Statement on the Cooperative Identity which contains the definition of a cooperative, the values of cooperatives, and the seven cooperative principles. The $2^{\text {nd }}$ principle is Democratic Member Control: "Cooperatives are democratic organisations controlled by their members, who actively participate in setting their policies and making decisions". In the US, the National Business Cooperative Association also adopts the same principles about democratic member control, and almost in every other country around the world, social enterprises are related with democratic management. In Greece, as mentioned earlier, all the legislation that is related with cooperatives and social enterprises, has clear guidelines for democratic procedures in the decision-making process (e.g. Law 4430/2016, Art.3, par. 4.

\subsection{Electronic Democracy}

Electronic democracy (or e-democracy) is a term that describes a broad scope of practices involving the online engagement of the public in political decision making and opinion forming (Korthagen et al, 2018). Lidén (2012) defined e-democracy as the use of information and communication technologies in democratic political processes concerning information, discussion and decision-making. The history of how electronic democracy developed though the last decades is described by Vedel (2006). Electronic democracy is gradually been recognized as an effective tool for promoting active political participation, information sharing, collective decision making, transparency and accountability.

Electronic democracy as a system can include various activities, from emails and forums, to live broadcasts and full electronic voting. The most common applications, nowadays, include online discussion forums, email communication with politicians, electronic campaigns, electronic surveys, electronic polls, blogs and e-petitions. Electronic democracy as a system is not fully implemented anywhere in the world, although several initiatives and applications have taken place both at national and local level. A recent report from the European 
Commission (2018, p.4), describes several electronic democracy initiatives and applications that have taken place both within and outside Europe.

The most distinctive feature of electronic democracy is electronic voting (e-voting). E-voting as a term encompasses a broad range of electronic systems that support the recording, the casting and/or the counting of votes in an election or referendum process (ACE, 2015). The design, trial and application of electronic voting systems has a history of more than 30 years, having started in Brazil in 1985. Today, several countries are examining the introduction of remote Internet voting and are trying pilot projects (e.g. Switzerland, Portugal, Brazil). A few countries have concluded the testing phase and either refrained from introducing it (e.g. Norway), or they have introduced it as a standard voting channel (e.g. Estonia). Because of security concerns there is, in some countries, a strong opposition to any kind of e-voting method, including voting machines in polling stations as well as the use of the Internet for voting at national elections or referendums. Alvarez \& Hall (2008) in their book describe the e-voting process and the challenges that are faced for its widespread acceptance and adoption.

It also worth mentioning that since 2009, the Council of Europe has issued Recommendation CM/Rec(2009)1, which is the first international legal instrument to set standards in the field of e-democracy. It offers all European governments and other stakeholders substantial guidelines and principles when dealing with e-democracy. It is accompanied by an Explanatory Memorandum and a number of practical tools prepared for those who require hands-on information about combining modern information and communication tools and democratic requirements and practice.

Despite the large potential and increased importance that e-democracy has received over the last decades, and the availability of technological tools, e-democracy adoption remains limited. Van Dijk (2012), in his research, concluded that after decades of e-democracy and e-participation practices at all levels of policy making, from municipalities to transnational bodies, the reality has been sobering. Evidence of the realization of e-democracy supporting public debate, deliberation and community building is mixed, with "no perceivable effect of these debates on decision making of institutional politics" (p.53). Norris et al (2012) concluded that at a local level, e-democracy innovations are scarce, financial support for development is rare and there is little enthusiasm for formalized e-democratic development amongst the key actors, including citizens. Varbanov (2015) highlights technology-related problems related with e-democracy adoption (as the availability of access to the Internet for individuals and businesses; the implementation of an e-government strategy etc.), as well as other types of obstacles as the Internet culture, readiness of citizens and authorities to implement the idea of e-democracy; and the availability of effective democratic mechanisms.

\subsection{Research Questions}

As a conclusion, electronic democracy and its features have low adoption rates, but are slowly starting to be used in various countries across the world, as their practical advantages are gradually being recognised and concerns about security are being dealt with. On the other side, social enterprises are rising as a strong alternative against the purely private economy, and for this type of enterprises one of the most distinctive features is democratic governance. However, the use of e-democracy applications in social enterprises remains unexplored. On this context, the current research tried to explore the possible connections between these two topics, by answering the following research questions:

a) Which e-democracy applications can be implemented in social enterprises?

b) Are Greek social enterprises familiar with electronic democracy?

c) Which electronic democracy applications do they use and how often?

d) What is the opinion of social enterprises about the practical value of e-democracy?

e) How willing would they be to try using e-democracy in their enterprise?

These research questions were answered through the methodology described below.

\section{Method}

In order to answer the first research question, there was an extensive online research, for free or paid, electronic democracy applications. For the rest 4 questions, the researchers organised an electronic survey, by e-mailing an online questionnaire to all the members of the Greek Social Economy Registry (1494 active members). The Greek Social Economy Registry is freely accessible online, in the website of the Greek Ministry of Labour, and the e-mail adresses used were those officially declared by each cooperative in their contact details. The e-mail provided an analytical description of the research and its goals, as well as the contact details of the researchers. 
For those cooperatives that chose to proceed with answering, a link was provided to the online questionnaire. The questionnaire had three parts:

- The first part was asking for basic demographic information about the social enterprise (year of establishment, prefecture, number of members, main sectors of activity).

- The second part had three questions: one about the social enterprise members' familiarity with computers and the Internet, a second about familiarity with electronic democracy and a third one about the use and frequency of use of various e-democracy applications.

- The third part had two closed and one open-end question. The first question was asking their opinion about the value of electronic democracy for social enterprises. The second was open-ended and was asking their opinion about the business aspects that e-democracy could be useful. The last question was closed-ended and was asking about their intention to use such applications. In the end there was space for general comments.

It must also be noted that except from the first part, all other questions were optional to answer. Answers were accepted during the period from the $5^{\text {th }}$ to the $30^{\text {th }}$ of September 2019.

\section{Results}

\subsection{Electronic Democracy Applications}

Through an online search, the researchers recorded a large number of electronic applications and platforms that can be used for electronic democracy purposes. These are the following:

A. Emails: Through emails the members of a social enterprise can communicate, exchange information, discuss, share news, express opinions and also vote, especially in cases of social enterprises with a small number of members.

B. Blogs: A blog is a website published on the World Wide Web that allows the publication of information and discussion among the visitors of the website. A blog can be free for everyone to visit, or accessible only for registered users, and editing rights may vary from one to many users. Through weblogs the members of a social enterprise, again can communicate, exchange information, discuss, share news, express opinions and also vote.

C. Forums: An Internet forum is an online discussion site where people can hold conversations in the form of posted messages. Depending on the access level of a user or the forum set-up, a posted message might need to be approved by a moderator before it becomes publicly visible. Forums are structured in "threads" or topics. Through electronic forums the members of a social enterprise can perform the same functions as those described before.

D. Electronic petitions: A petition refers to a formal written request, typically signed by many people, appealing to an authority with respect to a particular cause. An electronic petition is a form of petition which is signed online, usually through a form on a website. Visitors sign the petition by adding their details such as full name and email address. Social enterprise members can use petitions in order to address requests to the managers of an enterprise, local authorities or even the government.

E. Social Media: The term social media refers to electronic platforms and websites that enable the communication and interaction between groups of people. Social media are accessed online though phones, tablets or computers and allow the exchange of news, opinions, files and information among users. There are different types of social media, with different characteristics regarding their functionality. As with web blogs, through social media the members of a social enterprise, can communicate, exchange information, discuss, share news, express opinions and also vote.

F. E-voting platforms: Electronic voting platforms enable the casting and counting of votes in an election or referendum process. They provide the ability to the members of a social enterprise, especially when they are many in number, to vote for issues like the selection of the managing board, policies, strategic directions, mergers, the launch of new products and almost any other business aspect.

G. Business intelligence platforms: Business intelligence (BI) comprise the strategies and technologies used by enterprises for the analysis of business information. BI platforms can enable social enterprises to process, analyse and easily share data with all users within an enterprise. This procedure is very useful for reasons of transparency, decision making and control.

\subsection{Questionnaire Replies}

While sending out the informative email with the online questionnaire to the members of the Social Economy Registry, it was noted that 10 social enterprises' (SE) e-mail addresses were inactive, 34 e-mail addresses could not receive the e-mail for technical reasons (e.g. blocked) and 70 e-mail addresses were wrong. These technical 
problems reduced the sample to 1350 SEs. The answers that were received were 64, which gives a generally low response rate of $4.7 \%$. However, low response rates in such surveys in not uncommon. Below is a presentation of the responses that were received.

\subsubsection{Demographics}

The first question was asking about the SE's year of establishment. Answers are presented in Table and Diagram 1.

Table and Diagram 1. SE Year of Establishment

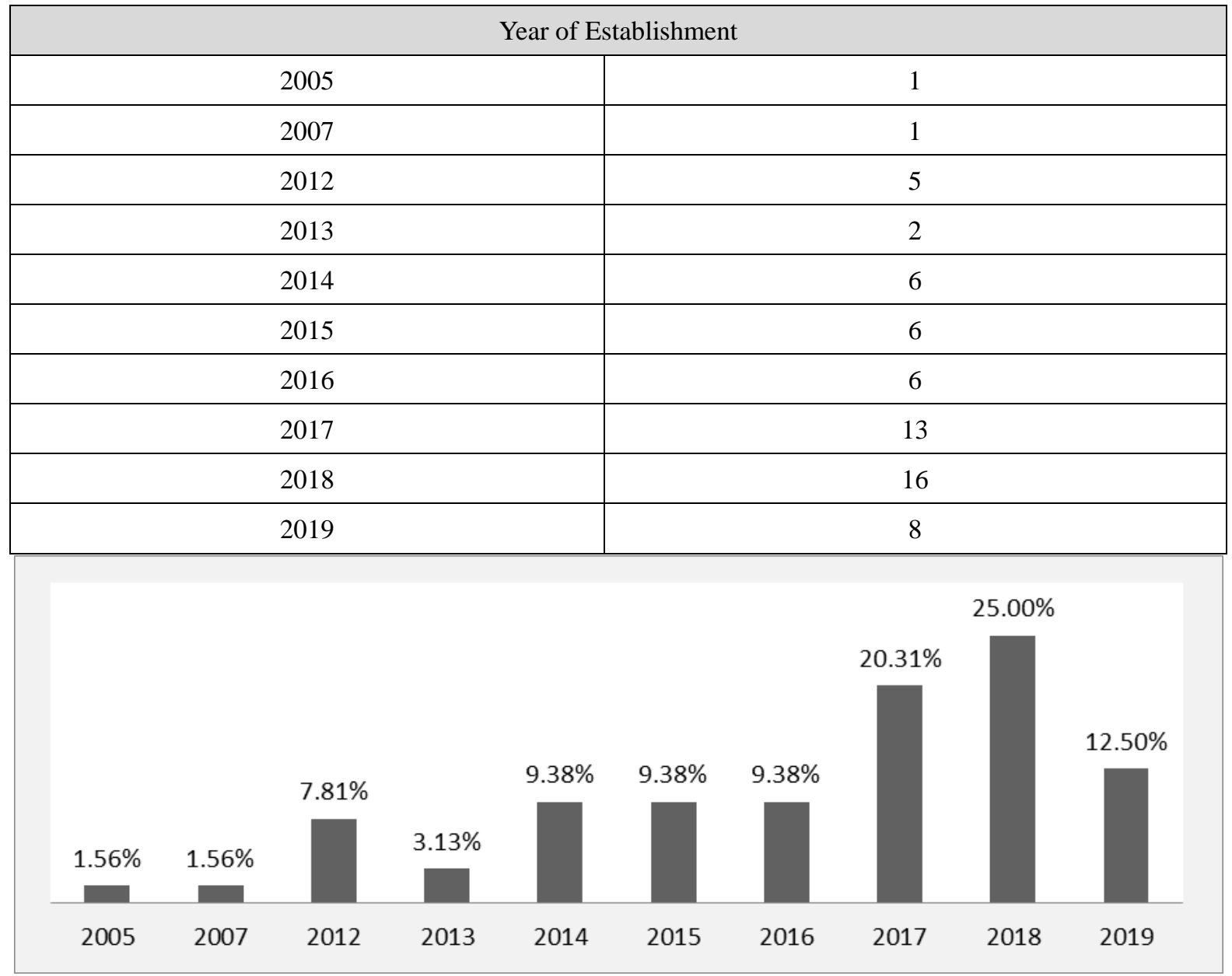

It is noticed that the oldest SE of the sample was established in 2005 and the newest one on 2019. Most of the SEs were established on $2018(25 \%)$ and $57 \%$ of them were established in the last three years. In general, most SEs of the sample are relatively new. Regarding their location in Greece, the results are presented at Table and Diagram 2, on a prefecture level. It is worth noting that Greece is divided in 52 prefectures.

Table and Diagram 2. SE’s Prefecture

\begin{tabular}{|c|c|}
\hline \multicolumn{2}{|c|}{ Prefecture } \\
\hline Thessaloniki & 10 \\
\hline Attiki & 23 \\
\hline East Attiki & 1 \\
\hline Achaea & 4 \\
\hline Arcadia & 1 \\
\hline
\end{tabular}




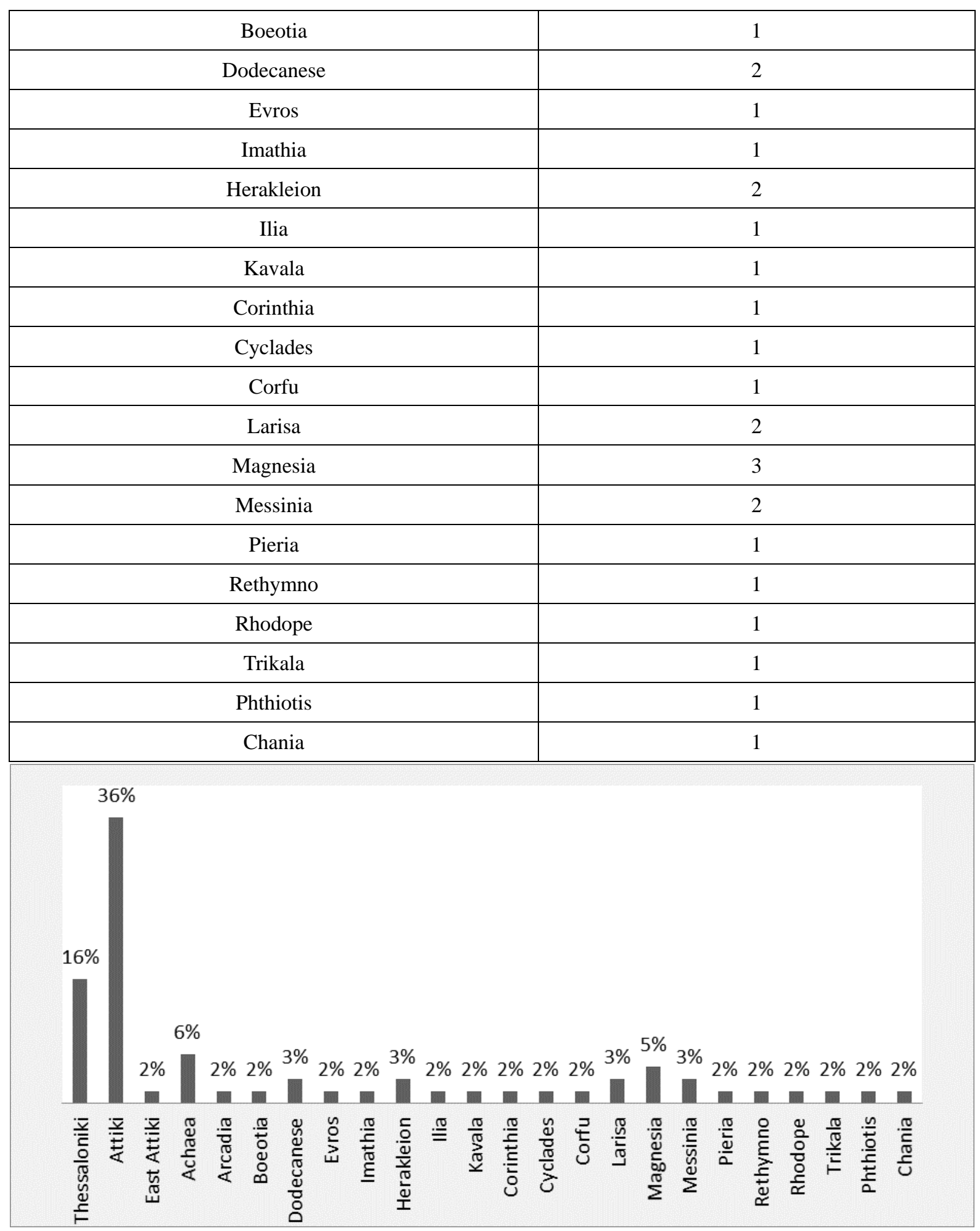

Answers were received from SEs from 24 different prefectures, which gives a coverage percentage of $46 \%$. In accordance to the national distribution of the population, most of the SEs that replied were from Attiki (35\%) and $15 \%$ from the prefecture of Thessaloniki. The number of members in each SE in presented in Table and Diagram 3. 
Table and Diagram 3. Number of Members

\begin{tabular}{|c|c|}
\hline \multicolumn{2}{|c|}{ Number of members } \\
\hline 3 & 1 \\
\hline 4 & 1 \\
\hline 5 & \multicolumn{2}{|c|}{40} \\
\hline 6 & 4 \\
\hline 7 & 3 \\
\hline 8 & 4 \\
\hline $10-20$ & 6 \\
\hline $20-50$ & 2 \\
\hline $50+$ & 3 \\
\hline
\end{tabular}

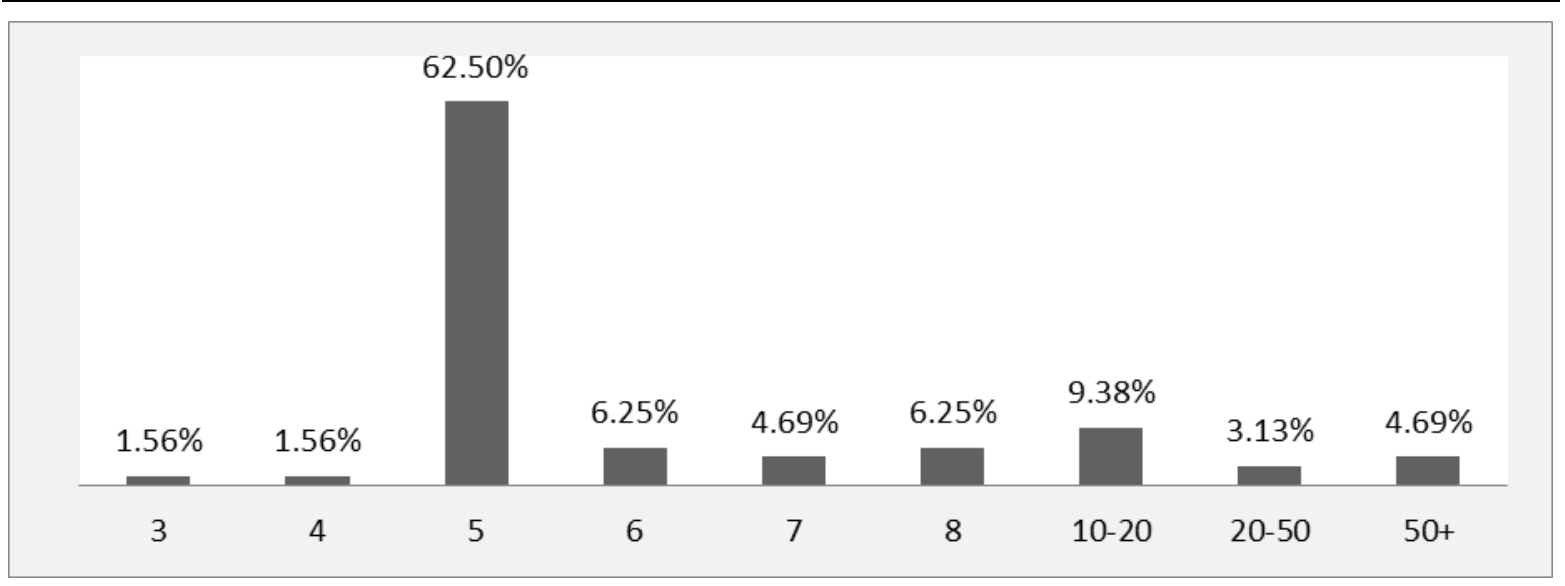

The minimum number of members was 3 and the maximum was 420. Most of the SEs had 5 members (62,50\%) and the second largest percentage was SEs with 10 to 20 members $(9,38 \%)$. The SEs main economic activities are presented in Table and Diagram 3. The categorization of economic activities used is the International Standard Industrial Classification of Economic Activities (ISIC) (Revision 4-2008), which is also the same with the classification used by the European Union (Statistical Classification of Economic Activities in the European Community, Rev. 2-2008-NACE).

Table and Diagram 4. Main Economic Activity

\begin{tabular}{|l|c|c|}
\hline \multicolumn{2}{|c|}{ Main economic activities } & 1 \\
\hline A. & Agriculture, forestry and fishing & 0 \\
\hline B. & Mining and quarrying & 3 \\
\hline C. & Electricity, gas, steam and air conditioning supply & 0 \\
\hline D. & Water supply; sewerage; waste management and remediation activities & 0 \\
\hline E. & Construction & 0 \\
\hline F. & Wholesale and retail trade; repair of motor vehicles and motorcycles & 11 \\
\hline G. & Transporting and storage & 0 \\
\hline H. & Accommodation and food service activities & 1 \\
\hline I. & & \\
\hline
\end{tabular}




\begin{tabular}{|c|c|c|}
\hline J. & Information and communication & 6 \\
\hline K. & Financial and insurance activities & 0 \\
\hline L. & Real estate activities & 0 \\
\hline M. & Legal and accounting activities & 7 \\
\hline N. & Administrative and support service activities & 7 \\
\hline O. & Public administration and defence; compulsory social security & 0 \\
\hline P. & Human health and social work activities & 5 \\
\hline Q. & Arts, entertainment and recreation & 5 \\
\hline R. & Other services activities & 13 \\
\hline S. & Activities of households as employers & 4 \\
\hline T. & Activities of extraterritorial organisations and bodies & 0 \\
\hline U. & Other activities & 0 \\
\hline
\end{tabular}

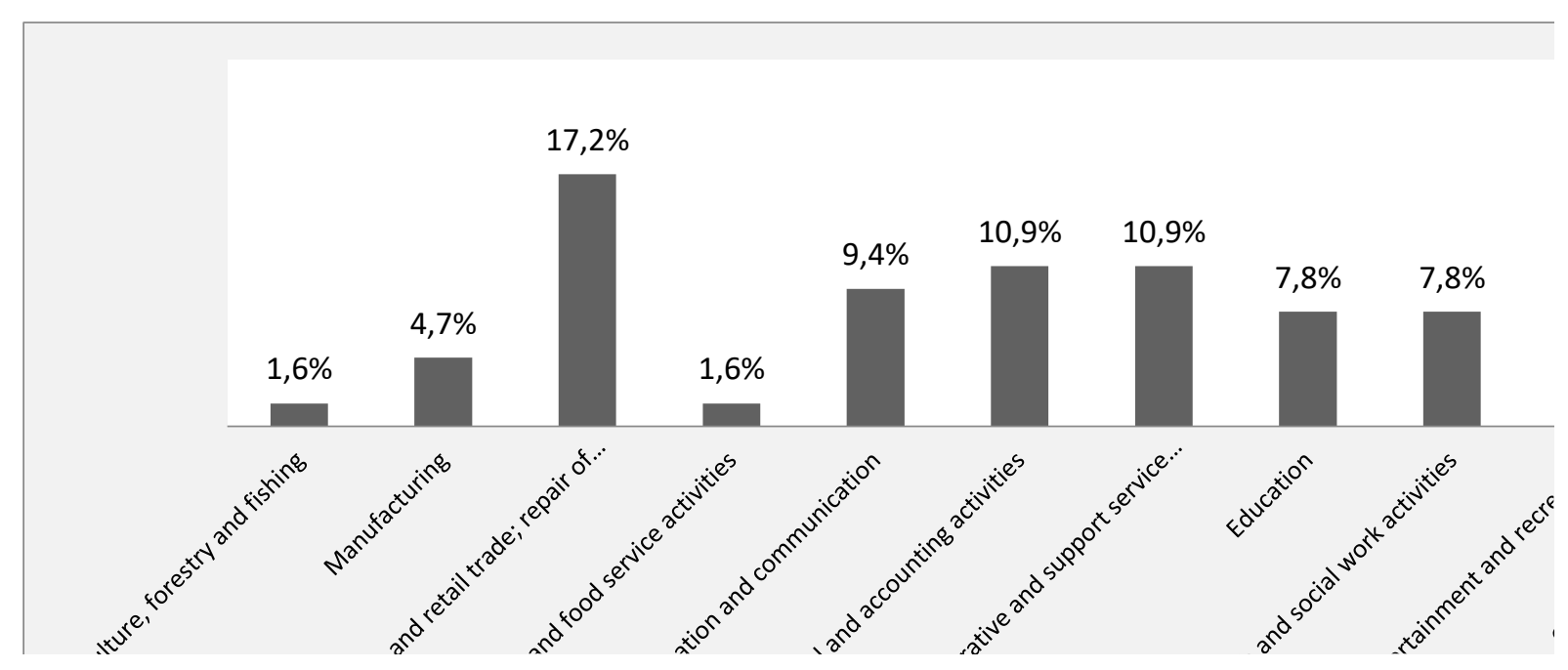

The SEs of the sample were active in 12 out of 21 NACE economic activities. The largest percentage was active in Arts, Entertainment and Recreation (20\%) and second was the Wholesale and Retail Trade (17\%). The second part of the questionnaire focused on the use of e-democracy by the SEs.

\subsubsection{Electronic Democracy Use}

The first question of the $2^{\text {nd }}$ part was asking about the familiarity of the members of the SE with computers and the internet. This question was replied by all the respondents. Results are presented in Table and Diagram 5. This question was replied from all the respondents (64). 
Table and Diagram 5. Familiarity with computers and the internet

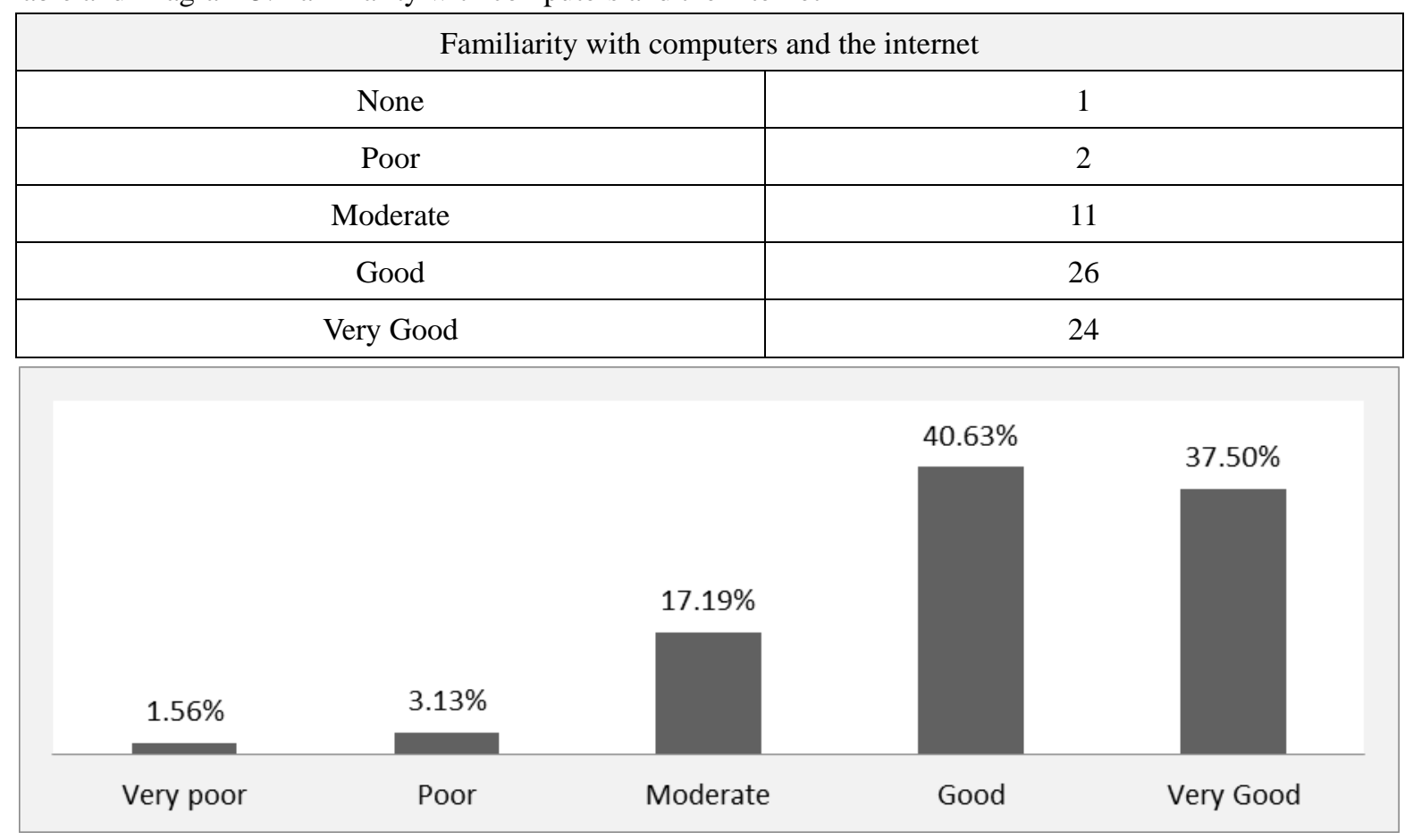

From the replies it can me noticed that $37 \%$ of the respondents consider that their members have very good with computers and the internet, and $40 \%$ good. Only $4 \%$ of the respondents considered the members of their SE to have very poor and poor computer skills. The next question was asking about familiarity with the term electronic democracy. Results are presented in Table and Diagram 6. Number of replies was 64.

Table and Diagram 6. Familiarity with the term Electronic Democracy

\begin{tabular}{|c|c|}
\hline \multicolumn{2}{|c|}{ Familiarity with the term Electronic Democracy } \\
\hline Very poor & 10 \\
\hline Poor & 15 \\
\hline Moderate & 22 \\
\hline Good & 12 \\
\hline Very Good & 5 \\
\hline
\end{tabular}

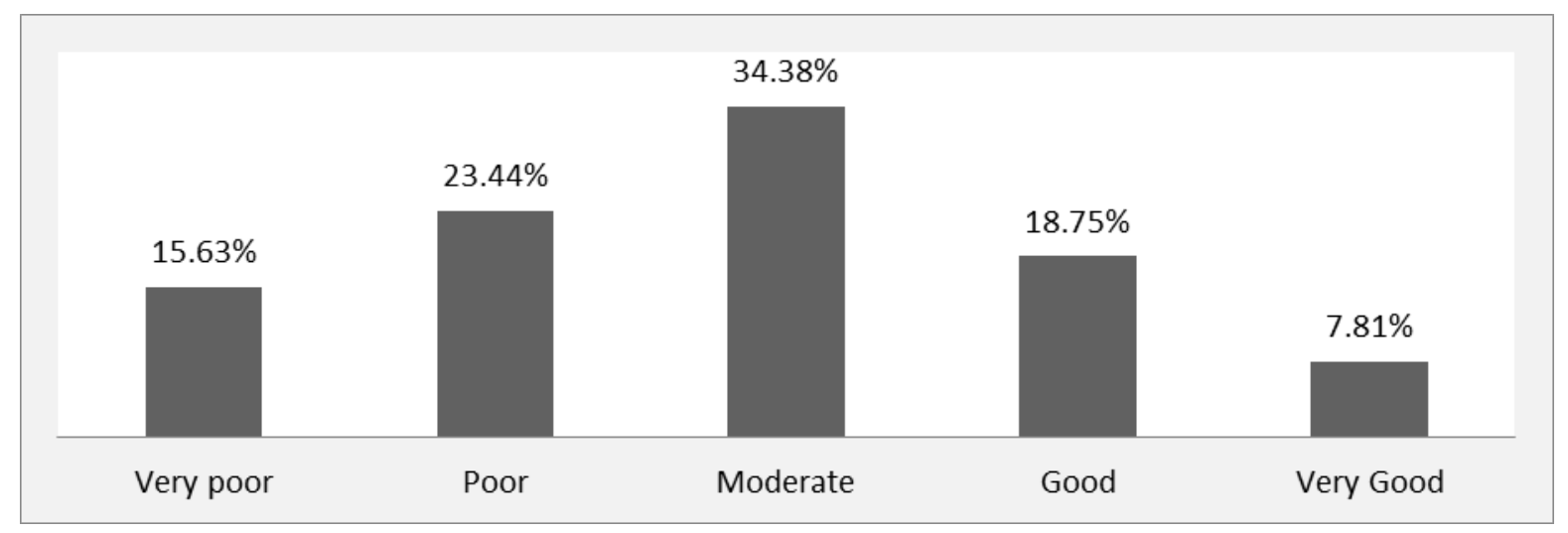


The cumulative percentage of respondents with good and very good familiarity is only $26,5 \%$. Most of the respondents replied that they have moderate familiarity (34\%), while $15 \%$ replied that they are not familiar with the term. Table and Diagram 7 present the results about the use and frequency of use of the electronic democracy applications that were recognised in part 4.1.

Table and Diagram 7. Use of various Electronic Democracy Applications

\begin{tabular}{|c|c|c|c|c|c|l|c|}
\hline & Emails & Blogs & Forum & $\begin{array}{l}\text { Electronic } \\
\text { petitions }\end{array}$ & $\begin{array}{l}\text { Social } \\
\text { media }\end{array}$ & $\begin{array}{l}\text { Electronic } \\
\text { voting } \\
\text { systems }\end{array}$ & $\begin{array}{l}\text { Business } \\
\text { Intelligence } \\
\text { systems }\end{array}$ \\
\hline Never & 1 & 27 & 10 & 36 & 5 & 36 & 39 \\
\hline Occasionally & 5 & 12 & 15 & 12 & 7 & 10 & 10 \\
\hline Fairly & 4 & 13 & 22 & 9 & 11 & 9 & 6 \\
\hline Often & 19 & 5 & 12 & 4 & 19 & 4 & 5 \\
\hline Very Often & 35 & 7 & 5 & 3 & 22 & 5 & 4 \\
\hline Replies & 64 & 64 & 64 & 64 & 64 & 64 & 64 \\
\hline & & & \multicolumn{7}{|c|}{ Percentages $(\%)$} & & & 60,94 \\
\hline Never & 1,56 & 42,19 & 15,63 & 56,25 & 7,81 & 56,25 & 15,63 \\
\hline Occasionally & 7,81 & 18,75 & 23,44 & 18,75 & 10,94 & 15,63 & 9,38 \\
\hline Fairly & 6,25 & 20,31 & 34,38 & 14,06 & 17,19 & 14,06 & 7,81 \\
\hline Often & 29,69 & 7,81 & 18,75 & 6,25 & 29,69 & 6,25 & 6,25 \\
\hline Very Often & 54,69 & 10,94 & 7,81 & 4,69 & 34,38 & 7,81 & \\
\hline
\end{tabular}

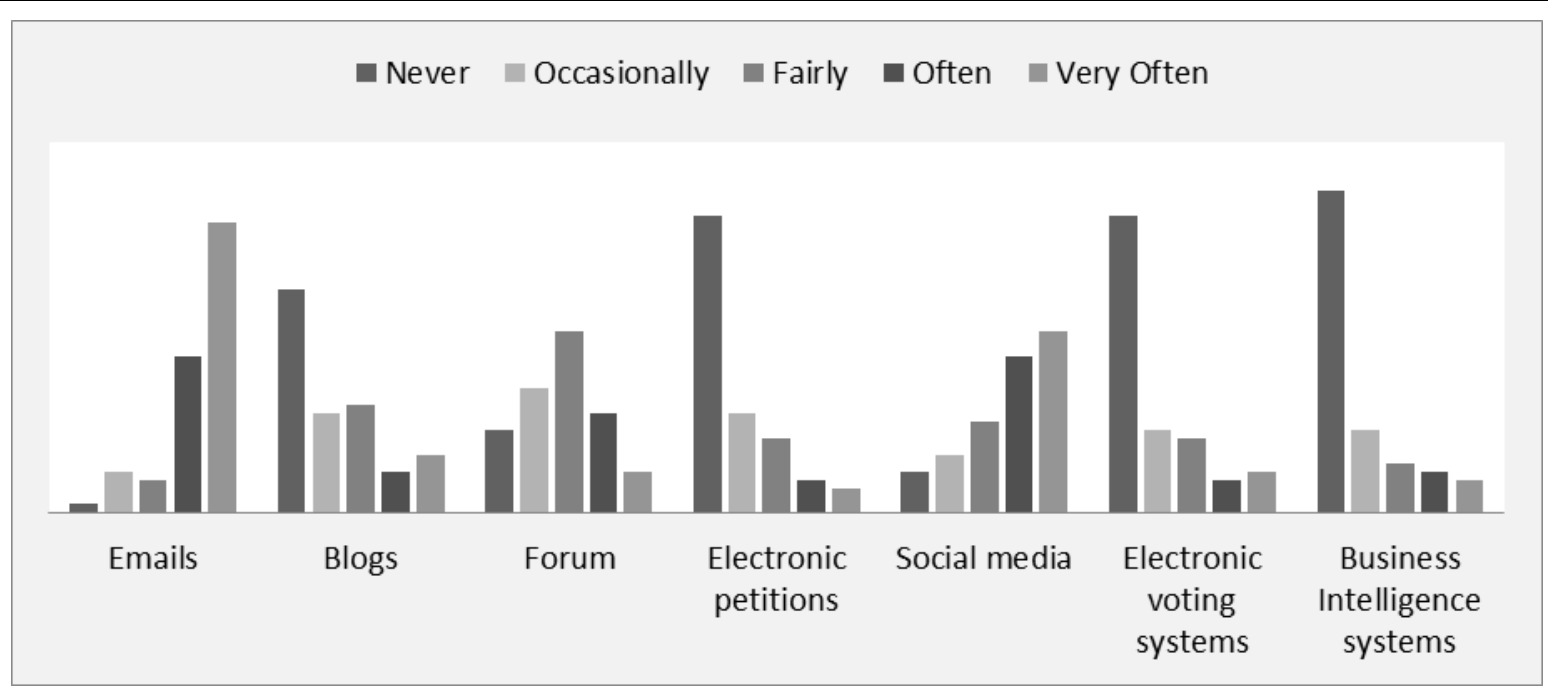

From the results it can be observed that some electronic democracy applications are being frequently used while others are not. We can observe frequent use of emails (cumulative percentage of often and very often use of $84,38 \%$ ) and Social Media (cumulative percentage of often and very often use of $64,07 \%$ ). Rarer is the use of forums $(26,56 \%)$ and blogs $(18,75 \%)$. It can also be noticed that applications that are not used at all by a large percentage of SEs, are BI systems (60.94\%), electronic voting (56\%), electronic petitions (56\%) and blogs $(42 \%)$.

\subsubsection{Opinions about Electronic Democracy}

The third and last part of the questionnaire was asking the SEs' opinion a) the usefulness of e-democracy, b) the business aspects that e-democracy can be useful and c) the willingness to merge its e-democracy applications in 
the SE's daily activities. The 62 replies that were received in the first question are presented in Table and Diagram 8.

Table and Diagram 8. Usefulness of e-democracy

\begin{tabular}{|c|c|}
\hline \multicolumn{2}{|c|}{ Usefulness of e-democracy } \\
\hline Not at all & 2 \\
\hline Slightly & 3 \\
\hline Moderately & 12 \\
\hline Very & 39 \\
\hline Very much & 6 \\
\hline
\end{tabular}

\begin{tabular}{|c|c|c|c|c|}
\hline & & & \multicolumn{2}{|l|}{$62.90 \%$} \\
\hline & & $19.35 \%$ & & \\
\hline $3.23 \%$ & $4.84 \%$ & & & \\
\hline Not at all & Slightly & Moderately & Very & Very much \\
\hline
\end{tabular}

From the replies we notice that $62 \%$ consider e-democracy useful and almost $10 \%$ consider it very useful. Only $3 \%$ consider e-democracy not useful at all and slightly useful is considered by $4.8 \%$. The second question was open ended and was asking their opinion about the business functions that they consider e-democracy more useful. The results are presented in Table and Diagram 9. The replies received were 50.

Table and Diagram 9. Business functions that e-democracy can be useful

\begin{tabular}{|c|c|}
\hline \multicolumn{2}{|c|}{ Business functions that e-democracy can be useful } \\
\hline Decision making & 19 \\
\hline Communication & 3 \\
\hline Management & 7 \\
\hline General operation & 3 \\
\hline Cooperation & 2 \\
\hline Transparency & 2 \\
\hline Relationships with customers & 1 \\
\hline Services offering & 1 \\
\hline Fighting bureaucracy & 3 \\
\hline Taxation & 1 \\
\hline I don't know & 5 \\
\hline None & 3 \\
\hline
\end{tabular}




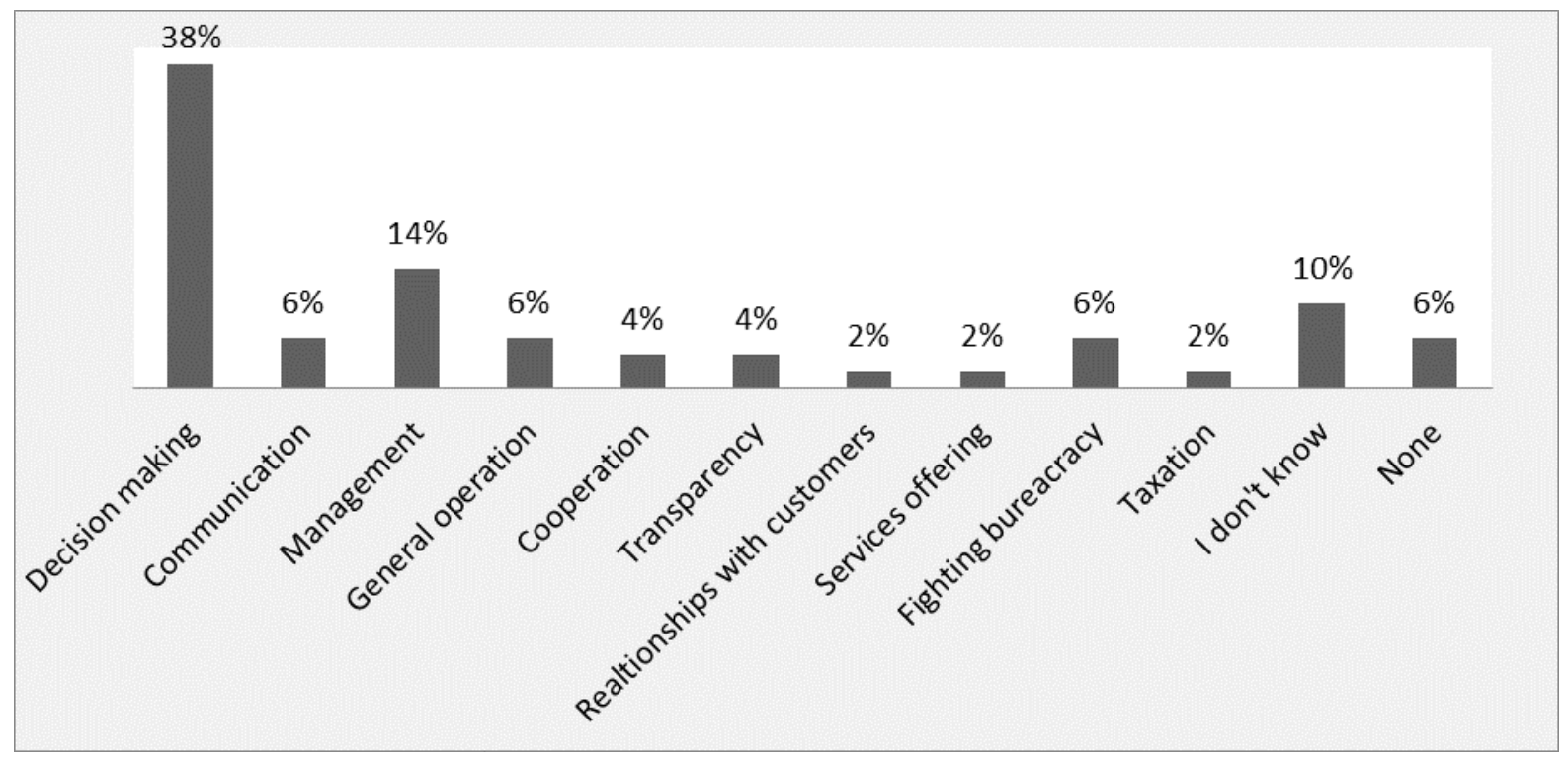

Most of the SEs' representatives replied that they consider e-democracy applications useful in decision making (38\%) and in the general management of the SE (14\%). Other high-frequency replies were communication between members; the general operation of the enterprise (6\%); and minimising bureaucracy $(6 \%)$. A $10 \%$ of the respondents mentioned that they do not know how e-democracy can be useful and $6 \%$ did not see any possible value of e-democracy. The last question was closed-ended and asked about their willingness to adopt e-democracy applications in the operation of their enterprise.

Table and Diagram 10. Willingness to try e-democracy applications

\begin{tabular}{|c|c|}
\hline \multicolumn{2}{|c|}{ Willingness to try e-democracy applications } \\
\hline None & 1 \\
\hline Low & 3 \\
\hline Moderate & 16 \\
\hline High & 33 \\
\hline Very high & 11 \\
\hline
\end{tabular}

\begin{tabular}{|c|c|c|c|c|}
\hline \multirow[b]{3}{*}{$1.56 \%$} & \multirow[b]{3}{*}{$4.69 \%$} & \multirow[b]{2}{*}{$25.00 \%$} & $51.56 \%$ & \multirow{2}{*}{$17.19 \%$} \\
\hline & & & & \\
\hline & & & & \\
\hline None & Low & Moderate & High & Very high \\
\hline
\end{tabular}

The replies show a high willingness to use e-democracy applications by a large percentage of SEs, with a cumulative percentage of high and very high willingness of $68,75 \%$. Only one SE replied that they are not interested in e-democracy at all and 3 expressed low willingness.

At the end of the online questionnaire, respondents were provided with free space for general comments. In total 
20 comments were received and they were the following: 5\% was asking for more information about e-democracy, $20 \%$ emphasized the importance of live human interaction among the members of the SE, $10 \%$ stressed the lack of familiarity with the term e-democracy, $5 \%$ was asking from the state to inform SEs about e-democracy, $5 \%$ commented on the lack of computer literacy, $10 \%$ expressed the willingness to adopt e-democracy applications and $40 \%$ gave other irrelevant answers.

\subsubsection{Cross Tabulation}

A further analysis is to focus on the answers of larger SEs by number of members, since they face more communication and participation challenges and they are more likely to benefit from e-democracy. In this case, as SEs with large number of members, were considered those that had more than 20 members, and they were only 5 in number. The familiarity with computers and the internet varies in their replies (they declared all levels apart from None). Familiarity with the term e-democracy is very low in 4 out of the 5 cases. Regarding e-democracy application use, e-mails are extensively used in all cases, blogs are used only by one SE, forums are used only by one SE, e-petitions are not used at all, social media present moderate and high use, electronic voting is used in just one case, and business intelligence programs use is either none or low. Moreover, 75\% consider e-democracy very useful, especially in decision making and $75 \%$ would be very willing to try using e-democracy applications.

\section{Conclusions}

The current research offers some useful insights on the current use of e-democracy applications by Greek social enterprises. The first research question was asking about the e-democracy applications can be implemented in social enterprises. The online search pointed out a number of applications that can be used for electronic democracy purposes, as emails, blogs, forums, social media, e-petitions, e-voting and business intelligence programs. The second research question was asking about the familiarity of Greek social enterprises with electronic democracy. The cumulative percentage of respondents with good and very good familiarity was only $26 \%$. Most of the respondents replied that they have moderate familiarity (34\%), while $38 \%$ replied that they were either not or poorly familiar with the term. The third question was asking about the electronic democracy applications that SEs use and their frequency. Greek SEs frequently use only emails and Social Media. Some SEs use forums and blogs, while BI, e-voting, e-petitions use is very limited. The fourth question regarded the opinion of social enterprises about the practical value of e-democracy. From the replies it was noticed that $62 \%$ consider e-democracy useful and almost $10 \%$ consider it very useful. Only $2 \%$ consider e-democracy not useful at all. Most of the SE representatives replied that they consider e-democracy applications useful in decision making (38\%) and in the general management of the SE (14\%). The last question was asking about the willingness of SEs to adopt e-democracy applications. The replies show a high willingness to use e-democracy applications by a large percentage of SEs, with a cumulative percentage of high and very high willingness of $68,75 \%$. Moreover, $75 \%$ of large SEs expressed willingness to adopt e-democracy practices.

The results of the current study are limited by the small response rate; however, as e-democracy practices are generally scarce in other political and economic activities, the researchers suspect that these results are not far from the national averages. Future research aims are to propose an e-democracy plan and apply it in a sample of willing social enterprises, in order to monitor its impact on the SE and its members.

\section{References}

ACE Electoral Knowledge Network. (2015). E-Voting. Retrieved from http://aceproject.org/about-en

Alvarez, M., \& Hall, T. (2008). Electronic Elections: The Perils and Promises of Digital Democracy. Princeton University Press.

Council of Europe. (2009). Recommendation CM/Rec(2009)1 of the Committee of Ministers to member states on electronic democracy (e-democracy). Brussels.

Dunoyer, C. (1830). Nouveau traité d'économie sociale. Paris: Sautelet et Cie.

European Commission, Directorate-General for Internal Market, Industry, Entrepreneurship and SMEs (2019). Social Economy. Retrieved from https://ec.europa.eu/growth/sectors/social-economy_en

European Commission, Directorate-General for Justice and Consumers. (2018). Democracy and elections. Special Eurobarometer, 477.

European Commission. (2011). Social Business Initiative: Creating a favourable climate for social enterprises, key stakeholders in the social economy and innovation. COM (2011) 682. (25.10.2011)

European Commission. (2018). Mapping Digital Social Innovation: 5 Digital Democracy. ePaństwo Foundation. 
Greek Legislation: Civil Code of 1946, Laws 602/914, 4430/2016, 1667/1986, 2716/999

Hellenic Ministry of Agricultural Development. (2019). Registry of Agricultural Cooperatives. Retrieved from http://www.minagric.gr

Hellenic Ministry of Labour and Social Affairs. (2019). Social and Solidarity Economy: SE Registry. Retrieved from https://aplo.yeka.gr

International Cooperative Alliance. (2015). Cooperative Identity. Retrieved from https://www.ica.coop/en/cooperatives/cooperative-identity

Korthagen, I., Keulen, I., Hennen, L., Aichholzer, G., Rose, G., Lindner, R., ... Nielsen, R. (2018). Prospects for e-democracy in Europe, European Parliament.

Lidén G. (2012). Is e-democracy more than democratic? - An examination of the implementation of socially sustainable values in e-democratic processes. Electronic Journal of e-Government, 10(1), 84-94.

Liger, Q., Stefan, M., \& Britton, J. (2016). Social Economy. Directorate General for Internal Policies, European Commission.

Mertens, S. (1999). Non-profit organizations and social economy: two ways of understanding the third sector. Annals of Public and Cooperative Economics, 70(3), 501-520. https://doi.org/10.1111/1467-8292.00122

Monzon, J. L. (1989). Las cooperativas de trabajo asociado en la literatura económica y en los hechos. Madrid: Ministerio de Trabajo y Seguridad Social.

Monzon, J. L., \& Chaves, R. (2012). The Social Economy in the European Union. European Economic and Social Committee.

National Cooperative Business Association. (2019). The 7 Cooperative Principle. Retrieved from https://ncbaclusa.coop/resources/7-cooperative-principles/

Norris, D., Reddick, C., \& Christopher, G. (2011). E-democracy at the American grassroots: Not now...not likely? Information Polity, 18(3), 201-216. https://doi.org/10.3233/IP-130312

Noya, A., \& Clarence, E. (2007). The Social Economy: Building Inclusive Economies. OECD. https://doi.org/10.1787/9789264039889-en

Uluorta, H. (2009). The Social Economy. Routledge. https://doi.org/10.4324/9780203884300

Van Dijk, J. (2012). Digital democracy: Vision and reality. Innovation and the Public Sector, 19, 49-62.

Varbanov, R. (2015). The Use Of The Internet To Support And Develop Democracy. Economic Archive, D. A. Tsenov Academy of Economics, Svishtov, Bulgaria, 3, 1-4.

Vedel, T. (2006). The Idea of Electronic Democracy: Origins, Visions and Questions. Parliamentary Affairs. 59(2), 226-235. https://doi.org/10.1093/pa/gs1005

Walras, L. (1896). Études d' Économie Sociale: théorie de la répartition de la richesse sociale. Lausanne.

Westlund, H. (2003). Form or contents? On the concept of social economy. International Journal of Social Economics, 30(11), 1192-1206. https://doi.org/10.1108/03068290310497521

\section{Copyrights}

Copyright for this article is retained by the author(s), with first publication rights granted to the journal.

This is an open-access article distributed under the terms and conditions of the Creative Commons Attribution license (http://creativecommons.org/licenses/by/4.0/). 